\title{
Reduced Heat Shock Period of 'Sharwil' Avocado for Cold Tolerance in Quarantine Cold Treatment
}

\author{
Kate A. Nishijima, Harvey T. Chan, Jr., Suzanne S. Sanxter, and \\ Edward S. Linse \\ U.S. Department of Agriculture, Agricultural Research Service, P.O. Box \\ 4459, Hilo, HI 96720 \\ Additional index words. Persea americana, precondition, heat treatment, cold storage, \\ chilling injury, fruit fly, heat shock
}

\begin{abstract}
A reduced heat shock period for 'Sharwil' avocado (Persea americana Mill.) before quarantine cold treatment is described. The shortened heat pretreatment period of 8 to 12 hours, rather than the originally recommended 18 hours at $38 \mathrm{C}$, is effective in reducing chilling injury symptoms when the pulp is at $\leq \mathbf{2 . 2 C}$ during 16 days of storage. The reduced durations and the range of pretreatment hours affords packinghouses greater efficiency and more flexibility and will reduce handling costs relative to the longer exposure.
\end{abstract}

'Sharwil' avocado fruit is a host for tephritid fruit flies when the trees are under drought conditions (Liquido et al., 1994). Therefore, avocados have been banned for further export from Hawaii to the U.S. mainland until a quarantine treatment is approved by the Animal and Plant Health Inspection Service (APHIS). A heat shock pretreatment (HSP) for inducing cold tolerance in 'Sharwil' avocado fruit before quarantine cold treatment has been developed (Sanxter et al., 1994). The HSP involves heating fruit at 37 to $38 \mathrm{C}$ (air) for 17 to $18 \mathrm{~h}$, followed by cooling at 20C (air) for $4 \mathrm{~h}$. Avocados then were placed in $1.1 \mathrm{C}$ (air) and stored for 16 days at $\leq 2.2 \mathrm{C}$ pulp temperature. This cold temperature storage has been approved as a quarantine treatment for many other fruit for the disinfestation of Mediterranean fruit fly [Ceratitis capitata (Weidemann)] (APHIS, 1994). Our report describes reduced periods ( $<17$ to $18 \mathrm{~h}$ ) of heat shock pretreatment at $38 \mathrm{C}$ that still induces fruit tolerance to chilling injury during storage at pulp temperatures of $\leq 2.2 \mathrm{C}$. This shorter pretreatment gives more flexibility in handling and reduces processing time.

Received for publication 14 Nov. 1994. Accepted for publication 24 Mar. 1995. We thank Myles H. Taniguchi for his help with statistical analysis. Reference to a company and (or) product named by the U.S. Dept. of Agriculture is only for purposes of information and does not imply approval or recommendation of the product to the exclusion of others that may also be suitable. The cost of publishing this paper was defrayed in part by the payment of page charges. Under postal regulations, this paper therefore must be hereby marked advertisement solely to indicate this fact.

\section{Materials and Methods}

'Sharwil' avocados were harvested from commercial orchards in the South Kona district, Island of Hawaii. Fruit were transported by truck to the U.S. Dept. of Agriculture, Agricultural Research Service, Tropical Fruit and Vegetable Research Laboratory, Hilo, Hawaii, within 24 to $48 \mathrm{~h}$. Fruit were culled for defects and placed in plastic mesh bins in lots of 20 or 40 fruit per treatment. Heat pretreatments were conducted at 37 to $38 \mathrm{C}$ in a $0.6-\mathrm{m}^{3}$ incubator (model RI-23-1060-A; Revco Scientific, Asheville, N.C.) with an air flow rate of 0.1 to $0.6 \mathrm{~m} \cdot \mathrm{s}^{-1}$ for $6,8,10,12$, or $18 \mathrm{~h}$. After heating, fruit were cooled at $\approx 23 \mathrm{C}$ for $4 \mathrm{~h}$ or until pulp temperature at the seed reached $\leq 28 \mathrm{C}$. Fruit then were transferred to a walk-in refrigerator (Forma Scientific, Marietta, Ohio) at $1.1 \mathrm{C}$. When pulp temperatures at the seed reached $\leq 2.2 \mathrm{C}$, fruit were placed in perforated (holes $6 \mathrm{~mm}$ in diameter, centered every $14 \mathrm{~cm}$ across each bag), $50 \times 76 \mathrm{~cm}, 0.08$-mm-thick, polyethylene bags (Shields Bag and Printing Co., Yakima, Wash.). The bagged fruit were placed in vented fiberboard boxes and held at $1.1 \mathrm{C}$ for 16 days with pulp temperatures $\leq 2.2 \mathrm{C}$. Pulp and air temperatures were monitored with a polycorder (Omnidata International, Logan, Utah) using thermistors calibrated at the start of each weekly experiment. The temperature profile of fruit heated for $18 \mathrm{~h}$ was the same as in the previous experiments (Sanxter etal., 1994). Control fruit were notheat shocked and were held for 16 days at $7 \mathrm{C}$ in vented fiberboard boxes without using perforated bags, as is done commercially. Previous work indicated that fruit subjected to quarantine cold storage without HSP were unacceptable (Sanxter et al., 1994); therefore, this treatment was excluded from our study.

After treatment, fruit were ripened at room temperature (23C) and evaluated for quality at the eating ripe stage. External quality was based on the degree of surface discoloration, pitting, and disease. Two experienced graders independently evaluated external quality on a scale of 1 to 5 , where $1=$ unacceptable, $2=$ marginally acceptable, $3=$ acceptable/marketable, $4=$ good, and $5=$ excellent fruit. The independent ratings were averaged per fruit, and per treatment. Internal acceptability was judged in consensus by cutting the fruit into cross-sections between the seed and peduncle to evaluate the vascular system and by cutting again distally to evaluate the pulp. Fruit were rated unacceptable internally if the pulp was lumpy, the vascular tissue was stringy, or the pulp or vascular tissue was more than slightly discolored or diseased (Sanxter et al., 1994). Data were analyzed using the $\mathrm{G}$ test (Sokal and Rohlf, 1969), which is a modified $\chi^{2}$ test used to analyze frequencies of occurrences in classes or categories. In our case, frequencies in each external quality rating category of external acceptability (i.e., the rating scale of 1 to 5) were analyzed to distinguish differences between treatments.

\section{Results and Discussion}

There were only slight differences between HSPs for external quality (Table 1). There were no significant differences between the external ratings of fruit that were exposed to HSP for 8,10 , or $12 \mathrm{~h}$ as shown by $\mathrm{G}$ values of $<15.57$ (Table 2). The 6- and 18-h HSPs resulted in similar responses ( $\mathrm{G}$ value slightly less than 15.5). However, the 6- and 18-h HSPs were significantly different from those for 8,10 , and $12 \mathrm{~h}$ (Table 2). Although the 6and 12-h HSPs had the same mean external rating (Table 1), the $\mathrm{G}$ test distinguished a difference between these two based on their rating distributions. The 10-h HSP resulted in the highest external rating and percent internally acceptable fruit of all HSPs (Table 1). The percentages of acceptable fruit based on the internal condition of the fruit were similar, and no HSP surpassed or equaled the quality of the nontreated control fruit stored at $7 \mathrm{C}$ (Table 1). Results for fruit treated for $18 \mathrm{~h}$ were

Table 1. Effect of duration of 38C (air) heat shock pretreatment before quarantine cold storage ( $\leq 2.2 \mathrm{C}$ pulp temperature, for 16 days) on appearance of avocado fruit. Control fruit (no heat shock) were held at $7 \mathrm{C}$ for 16 days and all fruit were ripened at room temperature $(\approx 23 \mathrm{C})$.

\begin{tabular}{lcccr}
\hline \hline Hours & $\begin{array}{c}\text { Mean } \\
\text { external } \\
\text { rating }^{z}\end{array}$ & $\begin{array}{c}\text { Fruit } \\
\text { internally } \\
\text { acceptable } \\
(\%)^{y}\end{array}$ & $\begin{array}{c}\text { No. } \\
\text { tests }\end{array}$ & $\begin{array}{c}\text { Total } \\
\text { no. } \\
\text { fruit }\end{array}$ \\
\hline 7 C (control) & 3.6 & 88.3 & 3 & 80 \\
6 & 2.9 & 72.8 & 4 & 159 \\
8 & 3.0 & 71.0 & 9 & 319 \\
10 & 3.1 & 78.6 & 8 & 299 \\
12 & 2.9 & 75.1 & 8 & 297 \\
18 & 2.7 & 68.9 & 8 & 259 \\
\hline
\end{tabular}

${ }^{2}$ External appearance was based on the following scale: 1 = unacceptable, $2=$ marginally acceptable, $3=$ acceptable $/$ marketable, $4=$ good, $5=$ excellent . 'Fruit were acceptable internally if pulp lacked defects or disease (see text). 
Table 2. External quality (frequency in quality categories) of 'Sharwil' avocados as a function of heat shock pretreatment (38C in air) duration (hours) before quarantine cold storage. Control fruit (no heat shock) were held at $7 \mathrm{C}$. After 16 days of storage ( 1.1 or $7 \mathrm{C}$ in air), all fruit were held at room temperature $(\approx 23 \mathrm{C})$ until ripe.

\begin{tabular}{|c|c|c|c|c|c|c|c|c|c|c|c|c|c|c|c|c|c|}
\hline \multirow{3}{*}{$\begin{array}{l}\text { Hours } \\
\text { heat }\end{array}$} & \multicolumn{11}{|c|}{$\begin{array}{l}\text { No. fruit } \\
\end{array}$} & \multirow{2}{*}{\multicolumn{6}{|c|}{ G-value matrix $(\mathrm{df}=8)^{\mathrm{z}}$}} \\
\hline & \multicolumn{9}{|c|}{ Quality rating category } & \multirow[b]{2}{*}{ Total } & \multirow[b]{2}{*}{ Means } & & & & & & \\
\hline & 1 & 1.5 & 2 & 2.5 & 3 & 3.5 & 4 & 4.5 & 5 & & & 7C control & 6 & 8 & 10 & 12 & 18 \\
\hline $7 \mathrm{C}$ (control) & 1 & 0 & 1 & 2 & 27 & 5 & 37 & 3 & 4 & 80 & 8.89 & & & & & & \\
\hline 6 & 0 & 5 & 22 & 11 & 101 & 6 & 13 & 1 & 0 & 159 & 17.67 & 76.47 & & & & & \\
\hline 8 & 5 & 2 & 26 & 27 & 184 & 32 & 37 & 6 & 0 & 319 & 35.44 & 66.60 & 20.97 & & & & \\
\hline 10 & 4 & 4 & 17 & 27 & 171 & 39 & 28 & 7 & 2 & 299 & 33.22 & 65.78 & 28.48 & 7.31 & & & \\
\hline 12 & 6 & 4 & 31 & 40 & 159 & 21 & 25 & 10 & 1 & 297 & 33.0 & 76.78 & 20.72 & 11.82 & 14.04 & & \\
\hline 18 & 8 & 9 & 51 & 29 & 141 & 8 & 12 & 1 & 0 & 259 & 28.78 & 114.97 & 15.30 & 46.08 & 57.90 & 28.07 & \\
\hline Total & 24 & 24 & 148 & 136 & 783 & 111 & 152 & 28 & 7 & 1413 & & & & & & & \\
\hline Means & 4.00 & 4.00 & 24.67 & 22.67 & 130.50 & 18.50 & 25.33 & 4.67 & 1.17 & & & & & & & & \\
\hline
\end{tabular}

${ }^{\mathrm{z}}$ Overall G value $=201.34(40 \mathrm{df}) ; \mathrm{G}$ values of two treatments $($ column $\times$ row $)<15.5$ nonsignificant at $P<0.05 \chi^{2}$.

similar to previous findings (Sanxter et al., 1994). Because differences in external and internal quality between treatments were not large, the HSP of $<18 \mathrm{~h}$ may enable the Hawaiian avocado industry to heat fruit for 8 to $12 \mathrm{~h}$, with $10 \mathrm{~h}$ being optimal, before the quarantine cold storage at $<2.2 \mathrm{C}$ pulp for 16 days, with minimal sacrifice of fruit quality.

\section{Literature Cited}

Animal and Plant Health Inspection Service. 1994 T107(a): Cold treatment schedules for Ceratitis capitata (Medfly), p. 5.62. In: Plant protection and quarantine treatment manual. U.S. Dept. of Agriculture, Hyattsville, Md.

Liquido, N.J., H.T. Chan, Jr., and G.T. McQuate. 1995. Hawaiian tephritid fruit flies (Diptera):
Integrity of the infestation-free quarantine procedure for 'Sharwil' avocado. J. Econ. Entomol. 88:85-96.

Sanxter, S.S., K.A. Nishijima, and H.T. Chan, Jr. 1994. Heat-treating 'Sharwil' avocado for cold tolerance in quarantine cold treatments. HortScience 29:1166-1168.

Sokal, R.R. and F.J. Rohlf. 1969. Biometry. Freeman, San Francisco. 